\title{
The effect of ethical tension and time pressure on job burnout and premature sign-off
}

\author{
Mohannad Obeid Al Shbail \\ Zalailah Salleh \\ Mohd Nazli Mohd Nor \\ Department of Accounting and Finance \\ Universiti Malaysia Terengganu (UMT), Malaysia
}

\section{Keywords}

Internal Auditors, Job Burnout, Premature Sign-Off, Ethical Tension, Time Pressure.

\begin{abstract}
The burnout is a common occurrence in psychology and a few applied business fields. Due to continuous acknowledgement in the practice community, this topic's academic acknowledgement has begun to surface in accounting literature. Previous studies in accounting revealed that burnout amid internal auditors are an important issue for auditors and employers. This paper examines the influence of ethical tension and time pressure on job burnout and its influence on premature sign-offs among internal auditors. To assess this, a total of 187 internal auditors who work in Jordanian public shareholding companies answered a questionnaire. The findings were that ethical tension and time pressure are important antecedents for job burnout, which increases internal auditors' level of premature sign-offs. Furthermore, the study found that the job burnout mediates the relationship between ethical tension, time pressure and premature sign-off.
\end{abstract}

Corresponding author: Mohannad Obeid Al Shbail

Email addresses for corresponding author: mohannadobeid87@gmail.com

First submission received: $29^{\text {th }}$ September 2017

Revised submission received: $15^{\text {th }}$ November 2017

Accepted: $18^{\text {th }}$ December 2017

\section{Introduction}

Studies in internal audit literature show that the audit quality can be negatively affected by dysfunctional audit behaviours. The term 'audit quality' has been defined in literature from different viewpoints. In general, although the audit quality concept is important, it has not been defined by technical standards. Currently, researchers have still failed to arrive at a consensus to understand its meaning. This is because audit quality is a complex concept and should not be confined to a single general meaning (Francis, 2011, Kilgore et al., 2014, Üç and Haxhiraj, 2015). However, due to the increasing significance of functions of internal audit and the scarce archival evidence on the quality of internal audit (Abbott et al., 2016), this study uses a substitute technique to capture dimensions of audit quality to ask auditors about the undertaking of quality reducing acts, i.e. dysfunctional audit behaviours as recommended by Svanström (2016).

Studies in internal audit literature shows that premature sign-off is in the top of dysfunctional audit behaviours among internal auditors (Ling and Akers, 2010). Different from underreporting (where the job is being carried out), the effect of premature audit sign-offs on audit quality is direct and it also violates the professional standards.

Burnout is a major cause of deviant behaviours by professionals, and is understood to have dysfunctional effects on their performance, behaviour and psychological wellness. Burnout symptoms have been reported anecdotally to occur in public accounting (Almer and Kaplan, 2002, Cannon and Herda, 2016, Fogarty et al., 2000, Chong and Monroe, 2015, Kingori, 2016), internal auditing (Fogarty and Kalbers, 2006, Fogarty and Kalbers, 2000, Kalbers and Fogarty, 2005, Kusel and Deyoub, 1983, Larson, 1997) and management accounting (Figler, 1980, Tipgoes and Trebby, 2011).

Job burnout includes a series of negative psychological encounters that reflects a 'wear out' due to being extensively exposed to the pressure of offering services to the others (Maslach, 1993). Job burnout is 
a crucial factor influencing auditors' behaviours (e.g. see Fogarty et al., 2000; Almer and Kaplan, 2002; Sweeney and Summers, 2002; Fogarty and Kalbers, 2006; Chong \& Monroe, 2015; Kingori, 2016). Nevertheless, notwithstanding its important effects on employees' behaviours, there are scarce researches on the prospective effect of job burnout on internal auditors' dysfunctional behaviours in the accounting academic literature.

Moreover, previous researches on dysfunctional behaviour have paid more attention to disposition or personality (e.g., Ng \& Feldman, 2008; O'Neill \& Hastings, 2011), organizational factors (e.g., Henle, 2005), and ethical ideology (e.g., Henle, Giacalone, \& Jurkiewicz, 2005) as predictors or antecedents of dysfunctional behaviour at work. Nevertheless, only a handful of researches have paid attention to job burnout as an important factor that may affect dysfunctional behaviour in employees. Whereas, the burnout studies investigating the role stress model in the context of auditing, have progressed to a stage where burnout becomes the mediator of association between job stressors and job outcome (Fogarty et al.,2000; Chong \& Monroe, 2015).

The purpose of this study is to build upon the idea of burnout and attend to the uniqueness of burnout from other criteria of work pressure like ethical tensions in the internal audit environment. Furthermore, this study constructs a series of proposed hypotheses that puts burnout in a role stress model proposed by Parker and DeCotiis (1983) that encompasses role stressors as antecedents, dysfunctional behaviours (e.g. premature sign-offs) as the consequences, and burnout as the important mediating variable. The suggested hypotheses are validated by the employment of data obtained from Jordanian internal auditors. The results obtained found that burnout is pertinent for internal auditors and has important adverse impacts that are not the same as the ones estimated from using only role stressors.

\section{Development of Hypotheses Ethical Tension}

The need to understand the effects and causes of ethics in the workplace has become crucial in recent times, more so than ever before, owing to the modern nature, size, and effects of businesses. In literature dedicated to ethics, there are several concepts that could assist in understanding such causes and effects. For instance, researchers have highlighted stress as a significant hazard within the workplace that could adversely impact physical health, psychological well-being as well as performance on the job (Kahn and Byosiere, 1992, Sauter and Murphy, 1995). A significant number of studies that focus on this phenomenon are based on the perspective of stressor-strain that contends the presence of innumerable factors that function as stressors, each of which can form a strain on the person and could bring about adverse outcomes.

To shed light on stress factors that relate to the ethical domain, the "ethical tension" is being defined as a psychological state born of an individual's uncertainty about his or her ability to fulfil relevant moral obligations (Reynolds et al., 2012) and when an individual knows of the right decision to choose but he is curtailed by the institutional/societal rules (Kinsella et al., 2008) or when "the ethical values of the employee are incongruous with the ethical values of other employees or the ethical values of the organization itself"' (Schwepker, 1999; p. 43).

Nevertheless, prior studies have evidenced the existence of tension in the auditing field. According to Sharif (2015), the scope of the job and the responsibilities that internal auditors face, necessitate them to attend to many interests - employers, shareholders, clients, the public, and other stakeholders. This leaves internal auditors in a dilemma when the professional standard of conduct that the internal auditors need to abide by does not align with the organisation's or client's expectations. Internal auditors generally require freedom to select their aims and they work within the contexts of brokered outputs (Raelin, 1989) therefore working within an environment in which they have less autonomy (Everett and Tremblay, 2014). In other words, internal auditors often face ideological, political and moral challenges that have largely been ignored in research (Everett \& Tremblay, 2014). Adding to this, those who are certified under the internal auditing profession and work in corporations are subjected to particular pressure. More often, they are the key people for management to ensure that corporate policies and procedures are being upheld, while abiding by the ethical and professional standards of their profession (Siegel et al., 1995). In this situation, ethical tension may arise. The ethical tensions are associated with a phenomenon whereby internal auditors face the dilemma between abiding by the code 
of conducts and professional ethics, and fulfilling company's or client's needs. Ethical tension has not been explored in prior studies in terms of its relationship with job burnout and premature sign-off in the context of auditing. Furthermore, no behavioural researches have extensively studied it either.

On the other hand, stress is brought about when a person's resources are being challenged by rising expectations and demands. As discussed earlier, when the values that employees and companies uphold contradict each other, a conflict is created, leading to stress and burnout. A recent research (Thorne, 2010) has evidenced that disputes between individual and organisational ethical values are linked with critical consequences like employee stress, absenteeism, reduced organisational commitment, and turnover intention. Similarly, Huhtala et al. (2011) found that ethical strain stemming from these situations are linked with high levels of burnout. Moreover, Jameton (1984) highlighted that ethical tensions as stressors related to an increase in job burnout. Based on the above, the following hypotheses are devised:

H1a: Ethical tension is positively associated with job burnout.

H1b: Ethical tension is positively associated with premature sign-off.

\section{Time pressure}

Time pressure stress is "the extent to which unreasonable deadlines and time demands are imposed" (Larson, 2004; p. 1126). When the time to accomplish the required tasks for an individual is not enough, the individual will experience time pressure (Matteson and Ivancevich, 1982). Following time pressures, deadlines become too tight and this is especially pressing when the ability to fulfil time demands is a crucial factor in the performance evaluation of an individual. For instance, a job with an extensive overtime and numerous deadlines that are hard to meet is highly stressful in general. As for internal auditing, it is regarded as a very stressful profession. As explained by Larson (2004), an internal auditing job is generally characterized by numerous deadlines. Time pressures may lead to job burnout as well as job dissatisfaction.

Meanwhile, a study by Larson (1997) among internal auditors concluded that there is a positive linkage between time pressure with job dissatisfaction, job burnout, and turnover intentions. In a mail survey, Larson and Murff (2006) attempted to measure job burnout among 1,500 internal auditors who were members of the American Institute of Certified Public Accountants (AICPA). The authors employed the SDS questionnaire to identify work-related stressors and Burnout Measure (BM) and based on the outcomes, time pressure appears to be the strongest cause of job burnout for internal auditors. For internal auditors, Brown and Mendenhall (1995) reported time pressure as a serious source of job stress. Time pressure being a serious concern has also been discussed by Wood and Wilson (1989). Furthermore, Azad (1994) stated that excessive time pressures contribute to internal auditors' premature sign-offs. Within the domain of public accounting, time pressure stress is a well-recognized phenomenon and it leads to dysfunctional audit behaviours (Gaertner and Ruhe, 1981, Snead and Harrell, 1991, Mohd Nor, 2011, Donnelly et al., 2003, Kelley and Margheim, 1990, Zakaria et al., 2013, Svanström, 2016). Svanström (2016) found that only premature signing-off has a positive significant association with time pressure compared with any other dysfunctional audit behaviours. Based on the above findings, the following hypotheses are devised:

H2a: Time pressure is positively linked with job burnout.

$\mathrm{H} 2 b$ : Time pressure is positively linked with premature sign-off.

\section{Job Burnout}

Over the recent years, "burnout", among many other aspects of concern in numerous professional areas, has gained attention of researches in terms of the rapidly advancing studies on stress and its adverse effects in personal and career life. Burnout effects are of a major concern for the employees and the organization since they coexist to achieve a mission (Herbert, 2011). Larson (1997) stated that the burnout effects experienced by professionals may include dysfunctional behaviours. Everall and Paulson (2004) stated the impaired practitioners, suffering from burnout are at the risk of violating a few ethical principles. However, there are no previous studies addressing the relationship between job burnout and PMSO in the internal and external audit profession, except Kingori (2016) study, which found a strong positive relationship between these factors. It is hypothesized that job burnout is directly proportional 
with premature sign-off.

H3: High job burnout levels are related with high number of premature sign-offs.

\section{The Mediating effect of Job Burnout}

Although burnout is hypothesized as an important mediating variable, it doesn't mean there would not be any direct impact of role stressors on job outcomes. This assertion is contingent upon two theoretical arguments as explained by Fogarty et al. (2000). Firstly, job outcomes can be affected both positively and negatively by role stressors. However, studies on burnout found that only the negative impacts of role stressors bring about burnout. On the contrary, burnout should not mediate the positive effects of role stressors. This reinforces the direct connection between job outcomes and role stressors. Secondly, when role stressors are not strong enough to bring about a burnout, a few of the negative consequences of role stressors on job outcomes could act as direct effects to induce burnout. As mentioned above, burnout will only happen when role stressors have enough magnitude to collectively challenge a person's resources. Role stressors under the threshold of burnout would not follow a mediated pathway, and could directly affect job outcomes.

Drawing these areas of research may also explain how the PMSO relate to burnout. For example, it is likely that some auditors, when faced with budget constraints, work longer hours but respond by underreporting chargeable time, while others respond to time constraints by prematurely signing-off an audit step before completing the necessary work. While the first response is likely to lead to burnout, the second may also lead to burnout but at significantly lower levels. It is argued in this paper that the effect of time pressure and ethical tension on PMSO has not been correctly captured due to not including burnout in the predictive statistical models. It is argued that burnout mediates the relationship between time pressure and PMSO.

H4a: Job burnout mediates the relationship between ethical tension and premature sign-offs.

H4b: Job burnout mediates the relationship between time pressure and premature sign-offs.

\section{The Model}

Figure 1 presents the proposed model and concludes the important proposed hypotheses (to be discussed). The interlinking paths in Figure 1 reveal that role stressors (ethical tension and time pressure) directly affect burnout and, in turn, burnout directly influences behavioural job outcomes (premature sign-off). In contrast, the suggested model with burnout as the key mediating variable acts as a point of departure from the majority of prior studies.

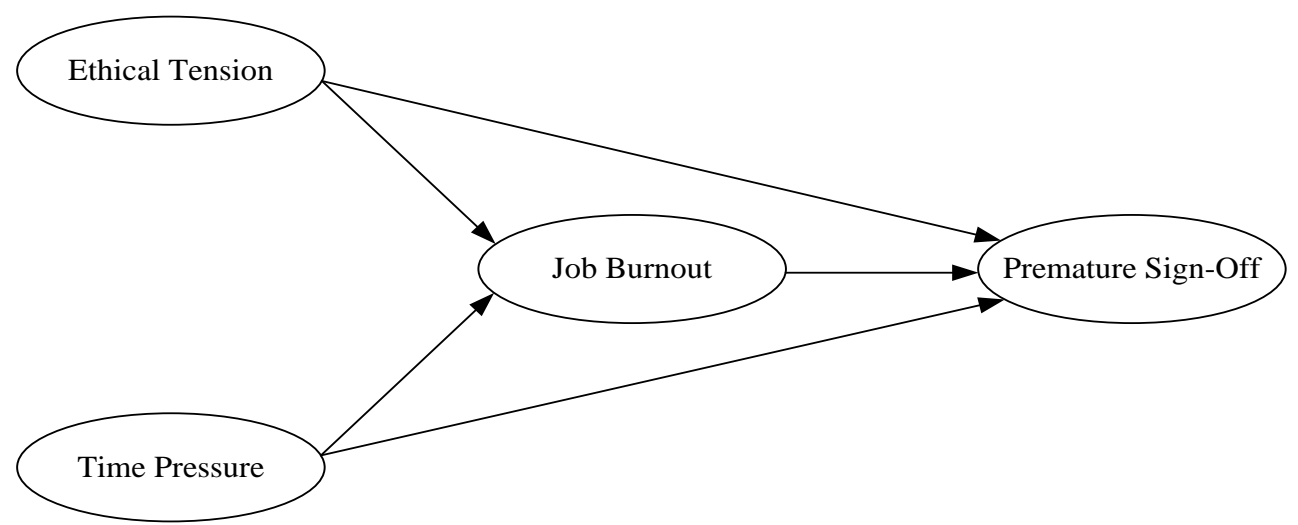

Figure 1. Conceptual Model Underpinning the Study

Methodology

Sample and Data Collection

A total of 385 internal auditors from 248 public shareholding companies in Jordan were selected for this study. All companies were listed in the Amman Stock Exchange ASE in 2015. The data was collected using a survey questionnaire over a period of five months from Sep 2015 to Feb 2016. Of the 385 questionnaires distributed, 298 were returned and 91 questionnaires were unusable due to missing information; thus, the response rate was $48.5 \%$ and the data analysis was based on 187 responses. The 
response rate can be considered satisfactory (Spector, 1992, Williams et al., 2004). Data was collected for various variables, including ethical tension, time pressure, job burnout, premature sign-off, and some demographic information. The average age of our participants was between 36 and 45 years, and participants had 11 to 15 years of working experience. Nearly all respondents $(92.5 \%)$ were male and most respondents $(72.7 \%)$ possessed no qualifications and certificates of the internal audit.

\section{Instruments}

The questionnaire survey is built based on the literature review above. This research basically employs the currently validated scales of prior researches on Likert-type scales with the range of response options starting from 1 to 7 . The original items in English were translated into Arabic. Via a meticulous process, the research preserves validity in order to assure that the questions are understood so as to prevent ambiguity.

Ethical Tension: To measure ethical tension we used twelve items designed to fit this study depending on an original version of the moral distress scale used by Corley et al. (2001), ethical dilemmas survey among senior public servants developed by Ehrich et al. (2004), an ethical pressure questionnaire, which was used to assess the pressure on auditors to engage in unethical work behaviour from Shafer (2002), and add one item for the ambiguous nature of moral rules (like code of ethics).

Time Pressure: This variable is measured using three questions based on Azad (1994) and Cook and Kelley (1988).

Job burnout: Job burnout was measured using the Pines and Aronson (1988) Burnout Measure. The Burnout Measure (BM; Pines \& Aronson, 1988) includes 21 items that are to be responded to using a 7 point scale ranging from $1=$ "never" to 7 = "always".

Premature sign-offs: This study uses twelve items depending on Ling and Akers (2010) instrument to measure the premature sign-offs in the internal audit environment.

\section{Data analysis}

In order to investigate the research model in Fig. 1, this research uses partial least squares structural equation modelling (PLS-SEM). PLS-SEM especially suits analysis of complex path models, where covariance-based SEM methods basically fail in providing an estimation (Ringle, Sarstedt, \& Straub, 2012). Furthermore, the PLS-SEM fits this study better because (1) this research focuses on predicting job burnout and effect it has on premature sign-offs by means of the stressors (Hair et al., 2016), which demands the use of PLS-SEM as a prediction-oriented method to SEM (Rigdon, 2012). (2) The research model in this research exhibits a complex structure. (3) The interconnection among JB and PMSO is in a development stage, and therefore forms a chance in exploring new phenomena (Ali et al., 2016), and $(4)$ the sample size $(n=187)$ is comparatively small.

\section{Results}

To investigate the PLS path model, this study employs the SmartPLS 3 software (Ringle, Wende, \& Becker, 2015) . Following Hair et al. (2016), the results' interpretation includes two stages: (1) the measurement model's assessment, and (2) the structural model's evaluation (see also, Ali and Park, 2016 and Ali et al., 2016, Obeid et al., 2017).

\subsection{Evaluation of Measurement model}

The results reveal that all minimum requirements were met by the measurement models, as illustrated in Table 1. First, this study used a cut-off value for factor loadings at 0.70 in significant level ( $\mathrm{t}$ value $>1.96$ and $p$-value $<0.05)$. A higher level of outer loading factors indicates a greater level of indicator reliability (Hair et al., 2013, 2011). Secondly, all composite reliabilities and Cronbach's alpha are larger than 0.70 which confirms the reliability of the measures' internal consistency (Wong, 2013). Furthermore, all average variance extracted (AVE) values exceed the threshold of 0.50, whereby it supports the convergent validity of the construct measures (Henseler et al., 2016). 


\begin{tabular}{|c|c|c|c|c|}
\hline Construct & Items & Loadings & Cronbachs Alpha & $\mathrm{CR}^{\mathrm{a}}$ \\
\hline & ET1 & 0.782 & & \\
\hline & ET3 & 0.784 & \multirow{3}{*}{0.810} & \multirow{4}{*}{0.868} \\
\hline \multirow[t]{4}{*}{ Ethical Tension } & ET4 & 0.730 & & \\
\hline & ET8 & 0.727 & & \\
\hline & ET9 & 0.744 & & \\
\hline & TP1 & 0.895 & \multirow{4}{*}{0.860} & \multirow{4}{*}{0.914} \\
\hline \multirow[t]{4}{*}{ Time Pressure } & TP2 & 0.835 & & \\
\hline & TP3 & 0.920 & & \\
\hline & JB1 & 0.847 & & \\
\hline & JB4 & 0.739 & \multirow{5}{*}{0.885} & \multirow{5}{*}{0.910} \\
\hline & JB8 & 0.776 & & \\
\hline \multirow[t]{2}{*}{ Job Burnout } & JB11 & 0.782 & & \\
\hline & JB12 & 0.783 & & \\
\hline \multirow{8}{*}{ Premature Sign-Off } & JB14 & 0.722 & & \\
\hline & JB17 & 0.728 & \multirow{7}{*}{0.899} & \multirow{7}{*}{0.921} \\
\hline & PMSO1 & 0.884 & & \\
\hline & PMSO2 & 0.829 & & \\
\hline & PMSO4 & 0.793 & & \\
\hline & PMSO5 & 0.792 & & \\
\hline & PMSO9 & 0.811 & & \\
\hline & PMSO10 & 0.773 & & \\
\hline \multicolumn{5}{|c|}{ Note: $\mathrm{CR}=$ composite reliability; $\mathrm{AVE}=$ average variance extracted } \\
\hline \multicolumn{5}{|c|}{$\begin{array}{l}\text { Table } 1 \text {. Measurement model } \\
\text { Lastly, the confirmation of discriminant validity for the analysis is made by } \\
\text { VE's square root to the correlations (Table } 2),(2) \text { a cross loading analysis, and, mos } \\
\text { e heterotrait-monotrait ratio of correlations (HTMT)'s values (Henseler et al., 2015) } \\
\text { onservative) threshold of } 0.85 \text { (Table 2). For more information see Appendix A. }\end{array}$} \\
\hline & Construct & 1 & 2 & 4 \\
\hline & $\begin{array}{ll}\text { 1. } & \text { ET }\end{array}$ & & & \\
\hline & 2. JB & 0.755 & & \\
\hline & 3. $\mathrm{PMSO}$ & 0.262 & 0.473 & \\
\hline & 4. TP & 0.448 & 0.667 & \\
\hline
\end{tabular}

Table 2. Heterotrait-Monotrait Ratio (HTMT)

Following the above analysis, for the final model, the reflective outer model was assessed for indicator reliability, internal consistency reliability and construct validity (convergent and discriminant). As was discussed, the model does not have any problem associated with these indicators.

\section{Structural model}

The structural model's results analysis draws on Hair et al. (2014). The analysis evidenced minimum collinearity in every series of predictors in the structural model, since the values of all variance inflation factor (VIF) are way lower than the threshold value which is 5. VIF values that are lower than five indicate that there is no problem of multicollinearity (see Appendix B) (Hair et al., 2011). Furthermore, the $\mathrm{R}^{2}$ values of job burnout (0.55) and premature sign-off $(0.22)$ are in agreement with the previous study (e.g. Svanström, 2016), which supports the in-sample predictive power of the model (Sarstedt et al., 2014). Likewise, results from blindfolding with an omission distance of 7 yield $\mathrm{Q}^{2}$ figures that are way beyond zero (see table 3 ) and therefore, the model's predictive relevance is supported in terms of out-of-sample prediction (Hair et al., 2012). Additional investigation of the composite-based standardized root mean square residual (SRMR) produces a value of 0.066 , that reaffirms the PLS path model's overall fit (Hair et al., 2014 and Henseler et al., 2014). 


\begin{tabular}{lcccc}
\hline Structural path & Path coefficient & $\begin{array}{c}\text { T Statistics } \\
(\mid \text { OSTDEV } \mid)\end{array}$ & P-Values & Conclusion \\
\hline H1a: ET -> JB & 0.492 & 6.747 & 0.000 & Supported \\
H1b: ET -> PMSO & -0.070 & 0.741 & 0.459 & Not supported \\
H2a: TP -> JB & 0.403 & 6.258 & 0.000 & Supported \\
H2b: TP -> PMSO & 0.221 & 2.274 & 0.023 & Supported \\
H3: JB -> PMSO & 0.343 & 3.332 & 0.001 & Supported
\end{tabular}

SRMR composite model $=0.066$

$\mathrm{R}^{2}$ Job Burnout $=0.556 ; \mathrm{Q}^{2}$ Job Burnout $=0.301$

$\mathrm{R}^{2}$ Premature Sign-Off $=0.220 ; \mathrm{Q}^{2}$ Premature Sign-Off $=0.128$

Table 3. Significant testing results of the structural model path coefficients

Applying the bootstrapping method in the assessment of path coefficients entails a least bootstrap sample of 5000 and the number of cases should equal the actual sample's number of observations (Hair et al., 2011). Moreover, the critical t-values for a two-tailed test are 1.65 (with a significance level of $10 \%$ ), 1.96 (with a significance level of 5\%), and 2.58 (with a significance level of $1 \%$ ). The empirical results are in agreement with most of the hypothesized path model relationships among the constructs. As anticipated, our results fully confirm to our expectations regarding the influence of ethical tension as an additional exogenous variable in the role stress model. Specifically, the standardised path coefficients shown in Table 3 confirm a significant positive association between ethical tension and burnout $(\beta=0.492$, p-value < 0.001 ) and a t-value of 6.747 , thus confirming Hypothesis 1a, aas opposed to the hypothesis, ethical tension has no direct effect on premature sign-offs which confirms hypothesis $1 \mathrm{~b}$. This study found also a significant positive relation between time pressure and job burnout $(\beta=0.403, \mathrm{t}=6.258, \mathrm{p}$-value $<0.001)$, therefore, it can be concluded that hypothesis $2 \mathrm{a}$ is supported. Table 3 also shows that time pressure and premature sign-offs have a positive relationship $(\beta=0.221$ at $\mathrm{t}=2.274)$ and are significant at a $\mathrm{p}$-value lower than 0.05 , indicating the support of hypothesis $2 \mathrm{~b}$. Our expectations regarding the influence of job burnout were also confirmed. Specifically, job burnout had a strong significant positive association (0.343) with premature sign-offs at a p-value of $<0.05$. This provided support for hypotheses 3 .

\section{Tests for mediation}

To test the mediation hypotheses ( $\mathrm{H} 4 \mathrm{a}$ and $\mathrm{H} 4 \mathrm{~b}$ ), we follow the procedures suggested by Hair et al. (2016). Specifically, to evidence a mediating effect, four conditions should be met. Firstly, the dependent variable should be predicted by the independent variable. Secondly, the mediator should be affected by the independent variable. Thirdly, the dependent variable must be affected by the mediator variable. Lastly, after taking the effect of the mediator into account, the effect of the independent variable on the dependent variable should be lowered or removed.

\begin{tabular}{lccccccc}
\hline & $\mathrm{a}$ & $\mathrm{b}$ & $\mathrm{a} * \mathrm{~b}$ & $\mathrm{C}$ & $\mathrm{C}^{\prime}$ & Method & \\
\cline { 2 - 7 } Hypothesis & T-value & T-value & T-value & T-value & T-value & $\begin{array}{c}\text { Variance } \\
\text { accounted for } \\
\text { (VAF) }\end{array}$ & $\begin{array}{c}\text { Boot- } \\
\text { strapping }\end{array}$ \\
\hline ET -> JB -> PSO & 0.492 & 0.343 & 0.169 & 0.100 & -0.070 & $1.69 \mathrm{a}$ & Full mediation \\
TP -> JB -> PSO & 0.403 & 0.343 & 0.139 & 0.360 & 0.221 & 0.39 & Partial Mediation \\
\hline
\end{tabular}

Note: aIn one case, "VAF can be greater than one when the total effect (c) is smaller than the indirect effect $(\mathrm{a} \times \mathrm{b})$. In situations where the VAF is greater than one and the direct effect (c) is not significant. In this situation, Shrout and Bolger (2002) and Nitzl et al. (2016) suggest considering a VAF equal to 1 as representing a full mediation."

Table 4:Test of Mediation using Bootstrapping Approach 
A mediating effect always exists when the indirect effect $(a \times b)$ is significant (Nitzl et al., 2016). The current mediation literature discusses two different types of mediation, full and partial mediation. A full mediation is indicated in the case where the direct effect (c) is not significant whereas the indirect effect $(a \times b)$ is significant, which means only the indirect effect via the mediator exists (Nitzl et al., 2016). Hence, all other situations under the condition that both the direct effect (c) and the indirect effect $(a \times b)$ are significant represent partial mediation (Nitzl et al., 2016). Moreover, VAF is to calculate the ratio of the indirect-to-total effect (Nitzl and Hirsch, 2016). This ratio is also known as the variance accounted for VAF value. VAF determines the extent to which the mediation process explains the dependent variable's variance. For a simple mediation, the proportion of mediation is defined as:

$$
V A F=a \times b / a \times b+c^{\prime}
$$

Hair et al. (2016) stated that is if the VAF is less than $20 \%$, one should conclude that nearly zero mediation occurs; a scenario in which the VAF is greater than $20 \%$ and lower than $80 \%$ could be classified as a typical partial mediation; and a VAF above $80 \%$ indicates a full mediation.

\section{Conclusion and Discussion}

As a study proposed, ethical tension and time pressure are important antecedents of burnout, which in turn predict dysfunctional behaviours by internal auditors. More specifically, ethical tension and time pressure have a positive correlation with job burnout, but only the time pressure has significant direct correlation with premature sign-off. Job burnout has a significant positive correlation premature sign-off. Results showed that job burnout also served as a full mediator between ethical tension and premature sign-off and a partial mediator between time pressure and premature sign-off. The study confirms and extends connections made in the prior literature, specifically in terms of relationships between the antecedents of burnout and the dysfunction outcomes. Our findings also add to the debate by confirming the central role of burnout as a mediating attribute in contributing to the ethical tension and premature sign-off relationships.

Moreover, as opposed to a plethora of work that has previously studied different professions (Chong and Monroe, 2015, Kingori, 2016), this study generates new knowledge in the relatively underresearched domain surrounding the causes and outcomes of burnout among internal auditors (Fogarty and Kalbers, 2006, Larson, 1997). The study therefore reveals several interesting findings with regard to dysfunctional audit behaviours research which has implications for audit quality (Svanström, 2016). Although this research helps in comprehending ethical tension's relationship with burnout and internal auditors' behaviours in Jordan, it also has a few limitations. Because the Jordanian shareholding companies' sample size is too big, it consumed time and money to gather data. Common method variance may also be a concern in studies that utilise the survey methodology. Although full collinearity tests were conducted and suggest that common method variance did not affect the data, it cannot be fully ruled out. Another limitation is that premature sign-offs in the related literature is distinguished into various dysfunctional audit behaviour types. The outcome from this research hints that internal auditor burnout is a meaningful construct that could use further research with a few other avenues to be considered. One potential area of focus would be to study other possible predictors. The present study included only two factors associated with burnout. Future studies can encompass a wider range of predictors that can predict job burnout such as workload, leadership behaviours and personality traits.

\section{References}

Abbott, L. J., Daugherty, B., Parker, S. \& Peters, G. F. 2016. Internal audit quality and financial reporting quality: The joint importance of independence and competence. Journal of Accounting Research, 54, 3-40.

Ali, M., Kan, K. A. S. \& Sarstedt, M. 2016. Direct and configurational paths of absorptive capacity and organizational innovation to successful organizational performance. Journal of Business Research, 69, 5317-5323.

Ali, M. \& Park, K. 2016. The mediating role of an innovative culture in the relationship between absorptive capacity and technical and non-technical innovation. Journal of Business Research, 69, 1669-1675.

Almer, E. D. \& Kaplan, S. E. 2002. The effects of flexible work arrangements on stressors, burnout, and behavioral job outcomes in public accounting. Behavioral Research in Accounting, 14, 1-34.

Azad, A. N. 1994. Time budget pressure and filtering of time practices in internal auditing: a survey. Managerial Auditing Journal, 9, 17-25.

Brown, D. \& Mendenhall, S. 1995. Stress and components of the internal auditor's job. Internal Audit, 10, 31-31. 
Cannon, N. H. \& Herda, D. N. 2016. Auditors' Organizational Commitment, Burnout, and Turnover Intention: A Replication. Behavioral Research in Accounting, 28, 69-74.

Chong, V. K. \& Monroe, G. S. 2015. The impact of the antecedents and consequences of job burnout on junior accountants' turnover intentions: a structural equation modelling approach. Accounting E Finance, 55, $105-132$.

Cook, E. \& Kelley, T. 1988. Auditor Stress and time-budgets. The CPA Journal, 58, 83-86.

Corley, M., Elswick, R., Gorman, M. \& Clor, T. 2001. Development and evaluation of a moral distress scale. Journal of Advanced Nursing, 33, 250-256.

Donnelly, D. P., Quirin, J. J. \& O'bryan, D. 2003. Auditor acceptance of dysfunctional audit behavior: An explanatory model using auditors' personal characteristics. Behavioral Research in Accounting, 15, 87-110.

Ehrich, L., Cranston, N. \& Kimber, M. 2004. Public sector managers and ethical dilemmas. Journal of the Australian and New Zealand Academy of Management, 10, 25-37.

Everall, R. D. \& Paulson, B. L. 2004. Burnout and secondary traumatic stress: Impact on ethical behaviour. Canadian Journal of Counselling, 38, 25.

Everett, J. \& Tremblay, M.-S. 2014. Ethics and internal audit: Moral will and moral skill in a heteronomous field. Critical Perspectives on Accounting, 25, 181-196.

Figler, H. R. 1980. Managing stress. Management Accounting, 62, 22-28.

Fogarty, T. J. \& Kalbers, L. P. 2000. An empirical evaluation of the interpersonal and organisational correlates of professionalism in internal auditing. Accounting and Business Research, 30, 125-136.

Fogarty, T. J. \& Kalbers, L. P. 2006. Internal auditor burnout: An examination of behavioral consequences. Advances in Accounting Behavioral Research. Emerald Group Publishing Limited.

Fogarty, T. J., Singh, J., Rhoads, G. K. \& Moore, R. K. 2000. Antecedents and consequences of burnout in accounting: Beyond the role stress model. Behavioral Research in Accounting, 12, 31-67.

Francis, J. R. 2011. A framework for understanding and researching audit quality. Auditing: A Journal of Practice $\mathcal{E}$ Theory, 30, 125-152.

Gaertner, J. F. \& Ruhe, J. A. 1981. Job-related stress in public accounting. Journal of Accountancy, 151, 68-74.

Hair, Ringle, M. \& Sarstedt, M. 2011. Pls-Sem: Indeed a silver bullet. Journal of Marketing theory and Practice, 19, 139152.

Hair , F., Hult, M., Ringle, C. \& Sarstedt, M. 2016. A primer on partial least squares structural equation modeling (PLS-SEM) (2nd edition), Sage Publications.

Hair, J., Ringle, C. \& Sarstedt, M. 2013. Editorial-partial least squares structural equation modeling: Rigorous applications, better results and higher acceptance. Long Range Planning, 46, 1-12.

Hair, J., Sarstedt, M., Hopkins, L. \& Kuppelwieser, V. 2014. Partial least squares structural equation modeling (PLSSEM) An emerging tool in business research. European Business Review, 26, 106-121.

Hair, J., Sarstedt, M., Ringle, C. M. \& Mena, J. A. 2012. An assessment of the use of partial least squares structural equation modeling in marketing research. Journal of the Academy of Marketing Science, 40, 414-433.

Henle, C. A. 2005. Predicting workplace deviance from the interaction between organizational justice and personality. Journal of managerial issues, 247-263.

Henle, C. A., Giacalone, R. A. \& Jurkiewicz, C. L. 2005. The role of ethical ideology in workplace deviance. Journal of Business Ethics, 56, 219-230.

Henseler, Ringle, C. \& Sarstedt, M. 2015. A new criterion for assessing discriminant validity in variance-based structural equation modeling. Journal of the Academy of Marketing Science, 43, 115-135.

Henseler, J., Dijkstra, T. K., Sarstedt, M., Ringle, C. M., Diamantopoulos, A., Straub, D. W., Ketchen Jr, D. J., Hair, J. F., Hult, G. T. M. \& Calantone, R. J. 2014. Common beliefs and reality about PLS: Comments on Rönkkö and Evermann (2013). Organizational research methods, 17, 182-209.

Henseler, J., Hubona, G. \& Ray, P. 2016. Using PLS path modeling in new technology research: updated guidelines. Industrial Management $\mathcal{E}$ Data Systems, 116, 2-20.

Herbert, M. 2011. An exploration of the relationships between psychological capital (hope, optimism, self-efficacy, resilience), occupational stress, burnout and employee engagement. Stellenbosch: Stellenbosch University.

Huhtala, M., Feldt, T., Lämsä, A.-M., Mauno, S. \& Kinnunen, U. 2011. Does the ethical culture of organisations promote managers' occupational well-being? Investigating indirect links via ethical strain. Journal of Business Ethics, 101, 231-247.

Jameton, A. 1984. Nursing practice: The ethical issues. Englewood Cliffs, NJ: Prentice-Hall.

Kahn, R. \& Byosiere, P. 1992. Stress in organizations. In: M. D. Dunnette E L. M. Hough (Eds). , Palo Alto, CA: Consulting Psychologists Press

Kalbers, L. P. \& Fogarty, T. J. 2005. Antecedents to internal auditor burnout. Journal of managerial issues, 17, 101-118.

Kelley, T. \& Margheim, L. 1990. The impact of time budget pressure, personality, and leadership variables on dysfunctional auditor behavior. Auditing-A Journal Of Practice $\mathcal{E}$ Theory, 9, 21-42.

Kilgore, A., Harrison, G. \& Radich, R. 2014. Audit quality: what's important to users of audit services. Managerial 
Auditing Journal, 29, 776-799.

Kingori, J. 2016. Burnout and Auditor Work Behaviours in Tanzanian Public Accounting Firms. Business Management Review, 11, 65-97.

Kusel, J. \& Deyoub, N. 1983. Internal auditor burnout. Internal Auditor, 40, 22-25.

Larson, L. 1997. Internal auditor job stress and turnover intentions Doctoral Dissertation, Cleveland State University.

Larson, L. 2004. Internal auditors and job stress. Managerial Auditing Journal, 19, 1119-1130.

Larson, L. \& Murff, E. 2006. An analysis of job stress outcomes among bank internal auditors: environmental job stressors, including politics and rewards, were more stress producing than workload stressors such as time pressure. Bank Accounting \& Finance, 19, 39-44.

Ling, Q. \& Akers, M. 2010. An Examination Of Underreporting Of Time And Premature Signoffs By Internal Auditors Review of Business Information Systems, 14, 37-48.

Maslach, C. 1993. Burnout: A multidimensional perspective, in: W. B. Schaufeli, C. Maslach, T. Marek, eds., Professional Burnout: Recent Developments in Theory and Research (Taylor and Francis, Washington, DC), 19-32.

Matteson, M. T. \& Ivancevich, J. M. 1982. Managing job stress and health, Free Press; Collier Macmillan.

Matteson, M. T. \& Ivancevich, J. M. 1987. Controlling work stress: Effective human resource and management strategies, Jossey-Bass.

Mohd Nor, M. N. 2011. Auditor stress: antecedents and relationships to audit quality. (Ph.D. dissertation, Edith Cowan University, Australia)

Ng, T. W. \& Feldman, D. C. 2008. The relationship of age to ten dimensions of job performance. Journal of applied psychology, 93, 392.

Nitzl, C. \& Hirsch, B. 2016. The drivers of a superior's trust formation in his subordinate: The manager-management accountant example. Journal of Accounting \& Organizational Change, 12, 472-503.

Nitzl, C., Roldan, J. L. \& Cepeda, G. 2016. Mediation analysis in partial least squares path modeling: Helping researchers discuss more sophisticated models. Industrial Management \& Data Systems, 116, 1849-1864.

O'neill, T. A. \& Hastings, S. E. 2011. Explaining workplace deviance behavior with more than just the "Big Five". Personality and individual differences, 50, 268-273.

Obeid, M., Salleh, Z. \& Mohd Nor, M. N. 2017. The mediating effect of job satisfaction on the relationship between personality traits and premature sign-off. Academy of Accounting and Financial Studies Journal, 21, 1-17.

Parker, D. F. \& Decotiis, T. A. 1983. Organizational determinants of job stress. Organizational behavior and human performance, 32, 160-177.

Pines, A. \& Aronson, E. 1988. Career burnout: Causes and cures, Free press.

Raelin, J. A. 1989. An anatomy of autonomy: Managing professionals. The Academy of Management Executive, 3, $216-228$.

Rigdon, E. E. 2012. Rethinking partial least squares path modeling: In praise of simple methods. Long Range Planning, 45, 341-358.

Ringle, Wende, S. \& Becker, J. 2015. "SmartPLS 3." Boenningstedt: SmartPLS GmbH. Retrieved from (http://www.smartpls.com). [Online].

Ringle, C., Sarstedt, M. \& Straub, D. 2012. A critical look at the use of PLS-SEM in MIS Quarterly. MIS Quarterly (MISQ), 36.

Sarstedt, M., Ringle, C. M., Henseler, J. \& Hair, J. F. 2014. On the emancipation of PLS-SEM: A commentary on Rigdon (2012). Long Range Planning, 47, 154-160.

Sauter, S. L. \& Murphy, L. R. 1995. Organizational risk factors for job stress, American Psychological Association.

Shafer, W. E. 2002. Ethical pressure, organizational-professional conflict, and related work outcomes among management accountants. Journal of Business Ethics, 38, 261-273.

Shapeero, M., Chye Koh, H. \& Killough, L. N. 2003. Underreporting and premature sign-off in public accounting. Managerial Auditing Journal, 18, 478-489.

Sharif, Z. 2015. Intention Towards Whistle-Blowing Among Internal Auditors in the UK. University of Huddersfield.

Siegel, P. H., O'shaughnessy, J. \& Rigsby, J. T. 1995. A reexamination of the Internal Auditors' Code of Ethics. Journal of Business Ethics, 14, 949-957.

Snead, K. \& Harrell, A. 1991. The impact of psychological factors on the job satisfaction of senior auditors. Behavioral Research in Accounting, 3, 85-96.

Spector, P. E. 1992. A consideration of the validity and meaning of self-report measures of job conditions. International Review of Industrial and Organizational Psychology West Sussex, England: John Wiley, 123.

Svanström, T. 2016. Time pressure, training activities and dysfunctional auditor behaviour: evidence from small audit firms. International Journal of Auditing, 20, 42-51.

Sweeney, J. T. \& Summers, S. L. 2002. The effect of the busy season workload on public accountants' job burnout. Behavioral Research in Accounting, 14, 223-245.

Thorne, L. 2010. The association between ethical conflict and adverse outcomes. Journal of Business Ethics, 92, 269-276.

Tipgoes, M. A. \& Trebby, J. P. 2011. Job-related stresses and strains in management accounting. Journal of Applied 
Business Research (JABR), 3, 8-14.

Üç, M. \& Haxhiraj, E. 2015. The Perceptions on IIA's Standards and Internal Audit Quality: Evidence from Albania Banking Industry. Mediterranean Journal of Social Sciences, 6, 147.

Williams, L. J., Gavin, M. B. \& Hartman, N. S. 2004. Structural Equation Modeling Methods In Strategy Research: Applications And Issues. Research Methodology in Strategy and anagement, 1, 303-346.

Wong, K. K.-K. 2013. Partial least squares structural equation modeling (PLS-SEM) techniques using SmartPLS. Marketing Bulletin, 24, 1-32.

Wood, D. J. \& Wilson, J. A. 1989. Roles and Relationships in Internal Auditing, Inst of Internal Auditors.

Zakaria, N. B., Yahya, N. \& Salleh, K. 2013. Dysfunctional Behavior among Auditors: The Application of Occupational Theory. J. Basic. Appl. Sci. Res, 3, 495-503.

\section{Appendixes}

Appendix A: Heterotrait-Monotrait Ratio (HTMT)

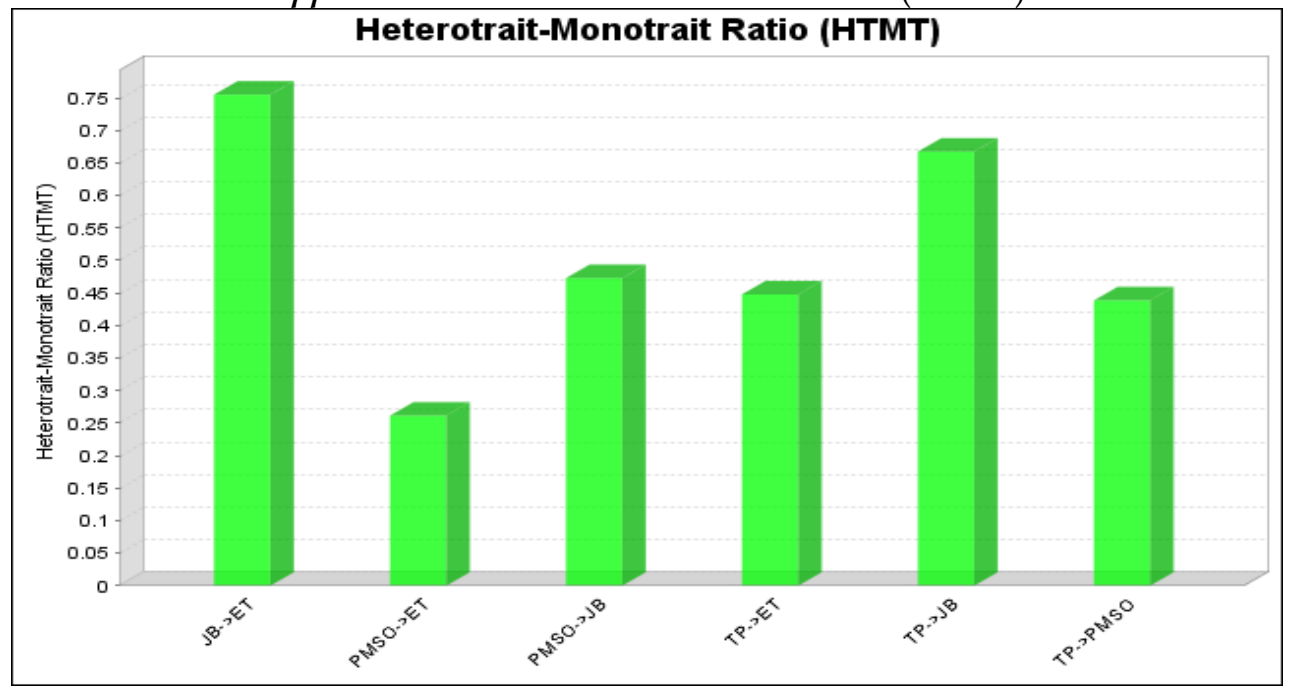

Appendix B: (Collinearity Statistics for the Reduced Model)

\begin{tabular}{|c|c|c|c|c|c|c|}
\hline \multicolumn{2}{|c|}{ Outer VIF values } & \multicolumn{5}{|c|}{ Inner VIF values } \\
\hline ET1 & 1.665 & & ET & JB & PMSO & TP \\
\hline ET3 & 1.638 & ET & & 1.172 & 1.717 & \\
\hline ET4 & 1.531 & $\mathbf{J B}$ & & & 2.254 & \\
\hline ETS & 1.605 & PMSO & & & & \\
\hline ET9 & 1.525 & TP & & 1.172 & 1.538 & \\
\hline JB1 & 2.436 & & & & & \\
\hline JB11 & 2.040 & & & & & \\
\hline JB12 & 1.966 & & & & & \\
\hline JB14 & 1.670 & & & & & \\
\hline JB17 & 1.743 & & & & & \\
\hline JB4 & 1.758 & & & & & \\
\hline JB8 & 2.088 & & & & & \\
\hline PMSOl & 3.231 & & & & & \\
\hline PMSOI0 & 1.812 & & & & & \\
\hline PMSO2 & 2.498 & & & & & \\
\hline PMSO4 & 2.088 & & & & & \\
\hline PMSO5 & 2.200 & & & & & \\
\hline PMSO9 & 2.028 & & & & & \\
\hline TP1 & 2.267 & & & & & \\
\hline TP2 & 1948 & & & & & \\
\hline TP3 & 2.663 & & & & & \\
\hline
\end{tabular}

